\title{
Earthquake-triggered landslides in southwest China
}

\author{
X. L. Chen, Q. Zhou, H. Ran, and R. Dong \\ Key Laboratory of Active Tectonics and Volcano, China Earthquake Administration, Beijing, 100029, China
}

Correspondence to: X. L. Chen (04chxl@sina.com)

Received: 31 May 2011 - Revised: 4 November 2011 - Accepted: 14 December 2011 - Published: 17 February 2012

\begin{abstract}
Southwest China is located in the southeastern margin of the Tibetan Plateau and it is a region of high seismic activity. Historically, strong earthquakes that occurred here usually generated lots of landslides and brought destructive damages. This paper introduces several earthquaketriggered landslide events in this region and describes their characteristics. Also, the historical data of earthquakes with a magnitude of 7.0 or greater, having occurred in this region, is collected and the relationship between the affected area of landslides and earthquake magnitude is analysed. Based on the study, it can be concluded that strong earthquakes, steep topography as well as fragile geological environment, are the main reasons responsible for serious landslides in southwest China. At the same time, it is found that the relationship between the area affected by landslides and the earthquake magnitude in this region are consistent with what has been obtained worldwide. Moreover, in this paper, it is seen that the size of the areas affected by landslides change enormously even under the same earthquake magnitude in the study region. While at the same tectonic place or fault belt, areas affected by landslides presented similar outline and size. This means that local geological conditions and historical earthquake background have an important influence on landslides distribution, and they should be considered when assessing earthquake-triggered landslide hazards at Grade 1 according to ISSMGE.
\end{abstract}

\section{Introduction}

As a kind of secondary disaster caused by strong earthquakes, earthquake-triggered landslides have drawn much attention in the world because of severe hazards it causes. In a mountainous region, sometimes a great loss of lives and properties caused by landslides even exceeds the losses caused by the earthquake itself. For example, in the Wenchuan earthquake of 12 May 2008, almost 20000 fatal- ities were due to landslides triggered by the shaking (Yin et al., 2009; Zhang, 2009). Different from the landslides caused by rainfall, earthquake-triggered landslides can take place in a comparatively wider region, and sometimes they are the most potentially destructive amongst the secondary geotechnical hazard associated with earthquakes. These large and widely distributed landslides usually cannot be prevented by current mitigating measures, nor can the regular measures used to monitor or predict rainfall-triggered landslides. Instead, the effective preventive measures are early warning and evacuation of vulnerable communities. In order to mitigate the damages, researches on the potential earthquakeinduced landslide zoning are being conducted in many countries at present (Jibson and Michael, 2009; Scott and Keefer, 2003; National Institute for Land and Infrastructure Management, Ministry of Land, Infrastructure, Transport and Tourism, 2004).

For the assessment of earthquake-triggered landslide hazards, it is necessary to establish correlations between seismic ground shaking and landslides in different geological, topographical and climatic conditions (Rodríguez et al., 1999). And, the assessment can be performed at different levels ranging from regional studies to the site-specific evaluation of individual slopes aimed to different demands (ISSMGE, 1999; Australian geomechanics society landslide zoning working group, 2007; Bommer et al., 2002). Keefer compiled an earthquake-triggered landslides database which included 40 historical world-wide earthquakes and, based on it, he studied the characteristics, geological environment of landslides, as well as the relations between landslide distribution and seismic parameters (Keefer, 1984). Rodriguez extended Keefer's work with other 36 world-wide earthquakes and used the similar approach to analyse his new data. The knowledge obtained by Keefer and Rodríguez are very similar except the presence of extreme outliers in some of the correlations (Rodríguez et al., 1999). The relationships between the area of landslides and earthquake magnitude 
should be the simplest and most important method in evaluating earthquake-triggered landslide hazards: the hazard is expressed as a binary function defining geographical limits within which landslides will be expected from an earthquake of specified magnitude and location (Bommer et al., 2002).

In Southwest China, due to its complex geological and geographical conditions, many strong earthquakes occurred frequently and are accompanied by a large number of landslides that was associated with the serious damage (Yi et al., 2002; Xu et al., 2005; Chen et al., 2010; Wang et al., 2009; Wen et al., 2004). For example, the destruction caused by landslides during Wenchuan Earthquake in China in 2008 was unexpected and shocked the world. This earthquake not only caused an amount of landslides of more than 15000 (Yin et al., 2009), also, it triggered some infrequent huge landslides along the seismic faults. Daguangbao landslide with estimated volume of 750 million $\mathrm{m}^{3}$ is the largest one among the individual landslides triggered by Wenchuan earthquake (Huang et al., 2009). Similarly, landslides caused by the Diexi earthquake in 1933 formed a large dam on the Min river, and later this dam collapsed and inundated the downstream region, resulting in thousands of deaths. Obviously, as a secondary seismic disaster, earthquake-induced landslides in the southwest China clearly constitute an important factor of the high level seismic risk to which the population and fragile environment of this region are exposed.

According to the latest earthquake statistics, there are 835 earthquakes with magnitude 4.7 or greater which occurred in the study area (Earthquake Disaster prevention department of State Seismological Bureau, 1995; Earthquake Disaster prevention department of China Earthquake Administration Bureau, 1999). Therefore, the data of landslides which occurred with these earthquakes would enrich the worldwide landslides database. Limited to incompleteness of historical documents, this paper will present just a part of earthquake-triggered landslides in southwest China and describe several earthquakes which triggered many landslides in the modern time and had formal post-earthquake investigations. Despite of imperfect data, earthquake-triggered landslides of southwest China provided in this paper will supplement the previous researches, as well as the worldwide data for a better understanding in landslide hazard. Also, the results obtained in this study will be a preliminary step in furthering the study on influencing factors related to landslide hazard assessment at the region scale.

\section{Regional setting}

The study region called Southwest China is located in the southeastern margin of Tibetan Plateau. This research actually focuses on a slightly larger area from $99-105^{\circ} \mathrm{E}$ and $23-$ $33^{\circ} \mathrm{N}$, which includes the western part of Sichuan province and the eastern part of Yunnan province in China (Fig. 1).

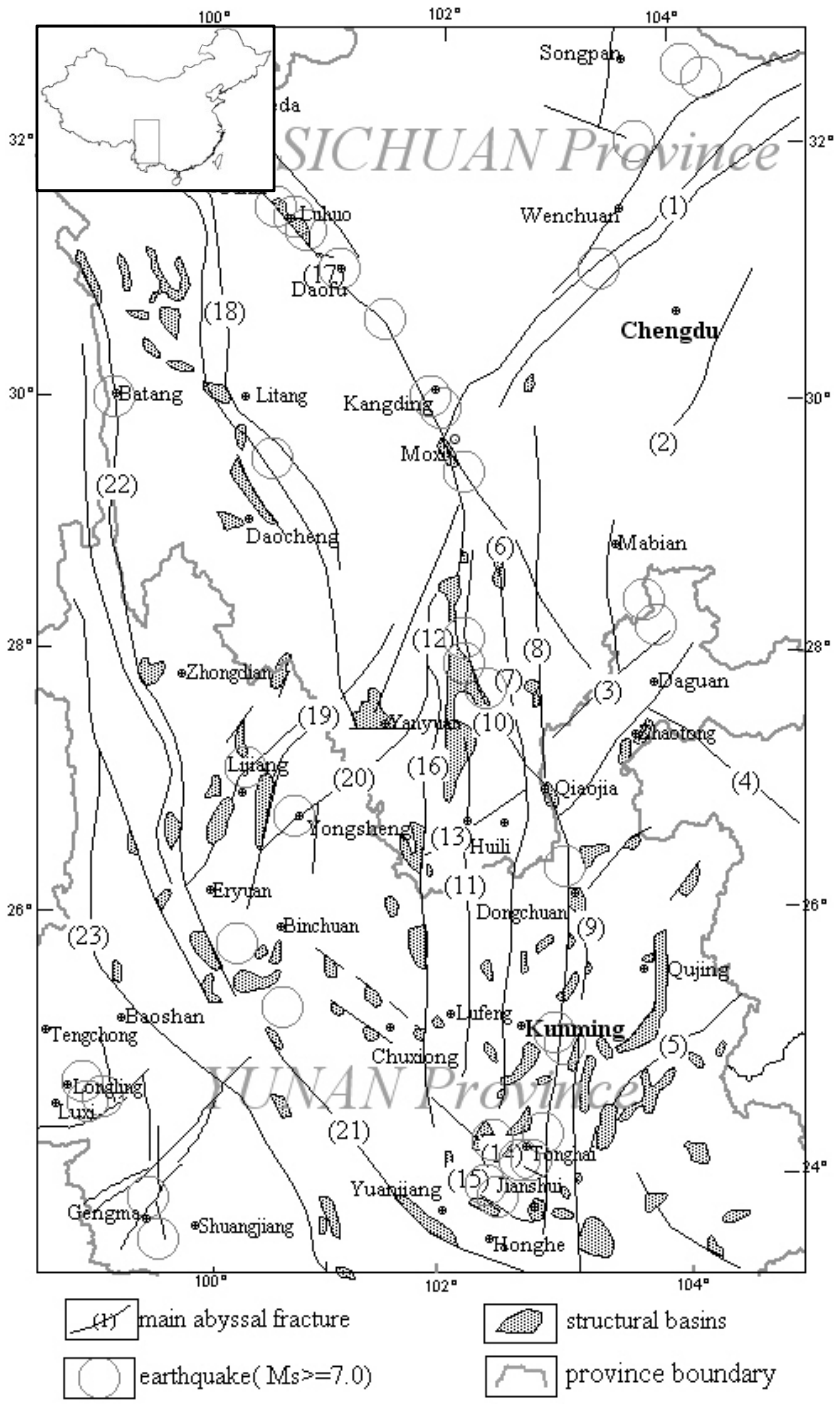

Fig. 1. Distribution of the main faults and structural basins in southwest China (revised from Southwest China Intensity Zoning Team of State Seismological Bureau), (1) Longmenshan fault; (2) EmeiJinyang fault; (3) Lianfeng-Qiaojia fault; (4) Yiliang-Shuicheng fault; (5) Mile-Shizong fault; (6) Puxionghe fault; (7) Xiluohe fault; (8) Luoxi fault; (9) Xiaojiang fault; (10) Zemuhe fault; (11) Anninghe fault; (12) Nanhe fault; (13) Ninghui fault; (14) Qujiang fault; (15) Shiping-Jianshui fault; (16) Mopanshan-Lvzhijiang fault; (17) Xianshuihe fault; (18) Litang fault; (19) Xiaojinhe fault; (20) Jinhe-Yongsheng-Binchan fault; (21) Yuanjiang fault; (22) Jinshajiang fault; (23) Lancangjiang fault.

\subsection{Geology and geomorphology}

The present structural outline of southwest China has resulted from the combination of Indo Sinian orogenesis, Yanshan detachment movement and the Himalayan thrust nappe movement. From the Cenozoic era, features of the fault blocks, which formed during Indo Sinian orogenesis and 
Yanshan movement, had changed due to the extension movement of the crust (Southwest China Intensity Zoning Team of State Seismological Bureau, 1985). As a result, there are around one hundred structural basins with various characteristics formed in this region. Also, the fault zones with NS, $\mathrm{NE}$ and NW trending directions dominate in this area (Zhang et al., 2003). Generally, the fracture zones are hundreds of kilometres in length, and have a width ranging from $10 \mathrm{~km}$ to $30 \mathrm{~km}$. They extend straight and are unaffected by the geomorphology. The fault basins, in general, change from $1 \mathrm{~km}$ to $10 \mathrm{~km}$ in width and $10-70 \mathrm{~km}$ in length, and are distributed mostly along the fault zones (Southwest China Intensity Zoning Team of State Seismological Bureau, 1985). In southwest China, the contrast between the elevations in this region is remarkable, high mountains always intersects with deep valleys. It is one of the most obvious tectonic features that deep fracture zones and the fault blocks created by the faults are very well-developed.

In the seventies of last century, a comprehensive study of earthquake intensity zoning in southwestern China is conducted by Southwest China Intensity Zoning Team, State Seismological Bureau of China. In total, there are 23 fracture zones with different lengths and trending directions marked in this region (Fig. 1). Among these fracture zones, Anninghe fracture zone and Mopanshan-luzhijiang fracture zone are so typical that they straightly extend in NS direction through this area, with magmatic rocks from different geological periods distributing along them, reflecting strong tectonic movements. During the long geological period, the fracture zones tend to have a significant effect on the advancing depositional history. Blocks adjacent to fracture zones are shown as uplifting with respect to sinking. For instance, the uplift blocks tend to consist of the early Palaeozoic sequence, while the fault basins are filled with Palaeozoic or Mesozoic formations. Regarding this area as a whole, there is a tendency for the NS fault zones, along which the basins are situated, to show a changeable elevation higher in the north and west with respect to the south and the east; and for the NW fault zones, higher in the northwest with respect to southeast. The variation in elevation for the basins in this region indicates the relationship between the rising of the Tibet Plateau and the subsiding of the basins. From Sinian Period to Quaternary, although almost all kinds of stratum are outcropped in this place, they have been cut in pieces due to the frequent and strong events which occurred (Fig. 2).

\subsection{Seismicity and seismic hazard}

Historically, southwest China is very prone to earthquakes. According to the latest earthquake statistics in the study area, there are 835 earthquakes with magnitude 4.7 or greater, in which there are 119 earthquakes of $6.0 \leq M<7.0,35$ earthquakes of $7.0 \leq M<8.0$, and 2 earthquakes of $M \geq 8.0$ (Fig. 3, Earthquake-resistant and damage prevention department of State Seismic Bureau, 1995; Earthquake-resistant

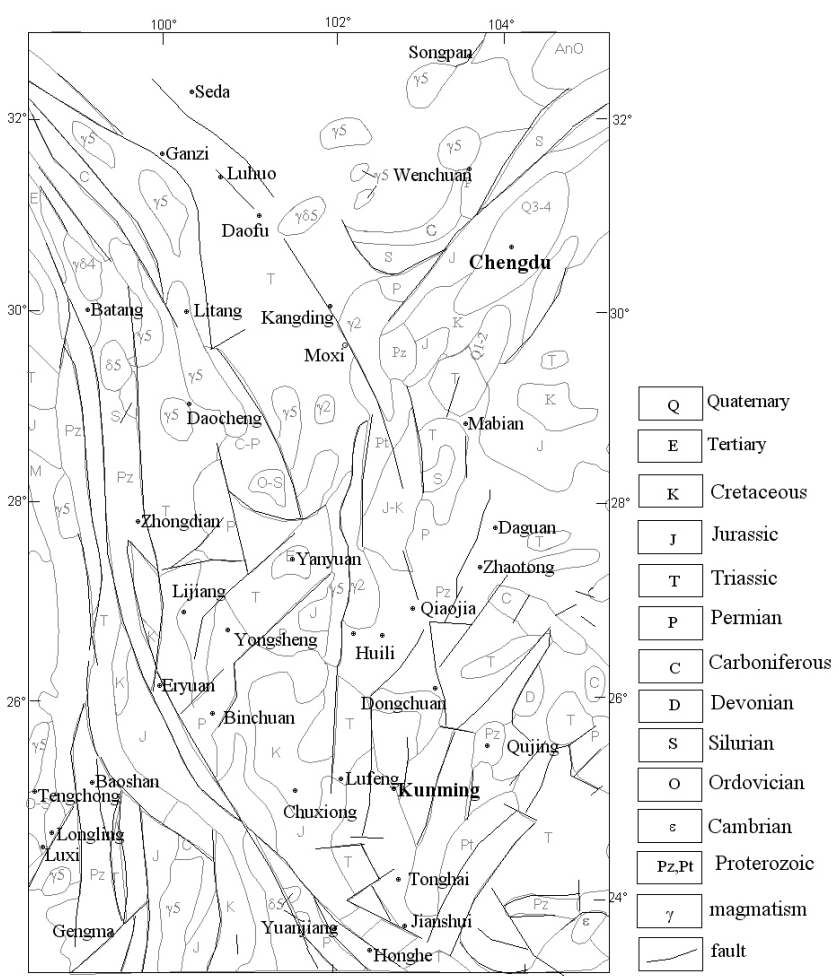

Fig. 2. Geological map in southwest China (Revised from Lithospheric dynamics atlas of China, 1989).

and damage prevention department of China Earthquake Administration Bureau, 1999).

Of the two 8.0 earthquakes, one is the 2008 Wenchuan earthquake recorded by seismograph instrumentals, the other is located at Songming region in Yunnan province in 1833. The latter's seismic parameters were obtained by inference from various historic records about the damages during this earthquake. Both of these two 8.0 earthquakes caused a huge number of landslides and collapses (Yin et al., 2009; Huang et al., 2009; Wang et al., 2009).

Research and field investigation find out that the strong earthquakes were always generated along the deep fracture zones, showing some close relationship between them (Southwest China Intensity Zoning Team of State Seismological Bureau, 1985; Zhang et al., 2003). Moreover, epicentres of several shocks are regularly aligned in the same structural zone. For example, at Xianshuihe seismic zone, there are more than 50 earthquakes documented with magnitude 4.7 or greater, in which there are 22 of 6.0 or greater. Especially, there are 4 earthquakes with magnitude 7.0 or greater occurred in this seismic zone since 1900.

Yi et al. (2005) studied the features of active tectonics and recurrence behaviour characteristics of strong earthquakes in this region, the results showed that the low velocity layers associated with the high conducting layers should be the cause of frequent earthquake occurrence in the upper crust (Yi et al., 2002; Xu et al., 2005). 


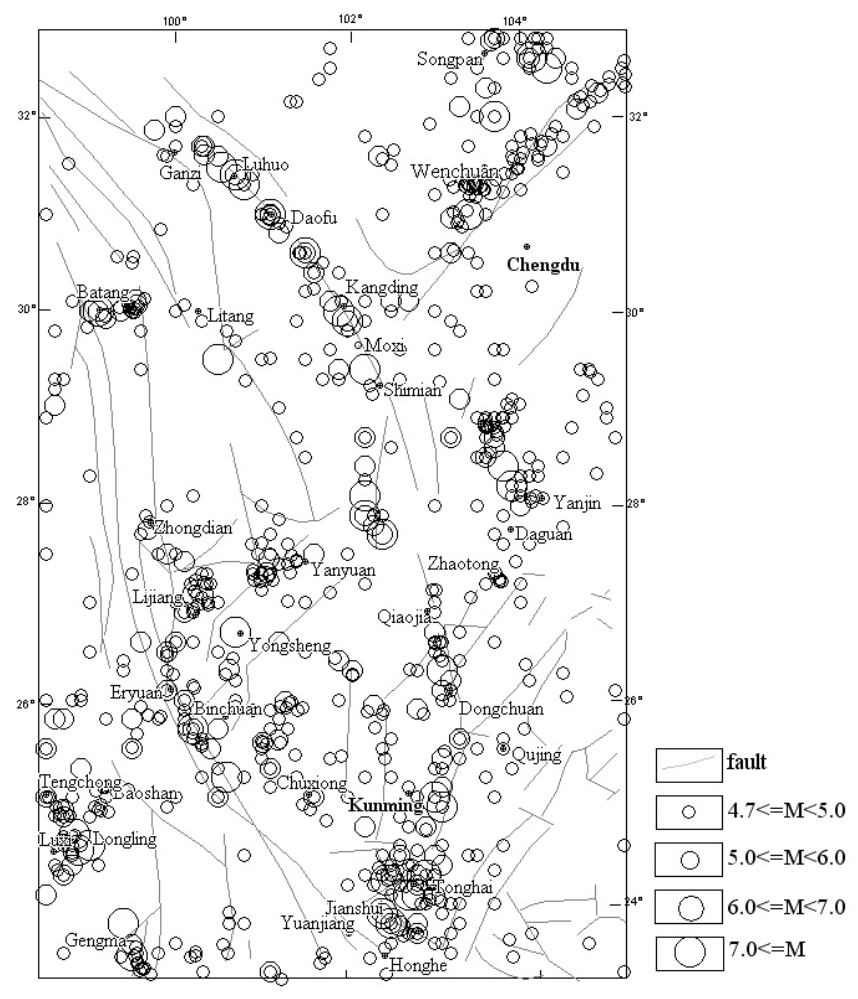

Fig. 3. Seismicity in southwest China (Revised from Southwest China Intensity Zoning Team of State Seismological Bureau, 1985).

\section{Landslides caused by earthquakes in southwest China}

\subsection{Earthquake database}

Reports and documents of earthquake-triggered landslides in southwest China have been collected from a wide variety of source, there are 835 earthquakes with magnitude 4.7 or greater occurred in the study area according to the latest earthquake statistics. Although the records of strong earthquakes $(M>=7.0)$ dates back to $814 \mathrm{BC}$, data of the occurrence of landslides in the events is extremely sparse prior to 1500 (Earthquake-resistant and damage prevention department of State Seismic Bureau, 1995). Limited to the development level of economy and culture in southwest China in the past time, not every earthquake which triggered landslides had a detailed investigation and records. As a result there is often uncertainty regarding the source parameters of some of the earlier events and, in particular, focal depths are often poorly determined. Not only in China, it is universal that historical earthquake-triggered landslide data is scarce in the world. The first formal and scientific post-earthquake investigation was undertaken following the earthquake swarm in Calabria, Italy in 1783 (Keefer, 2002). Before it, the historical accounts of landslides in earthquakes are typically so incomplete and vague that conclusions based on these accounts are of limited usefulness (Keefer, 2002). Neverthe- less, historical landslide documents are still the important base for the landslides research. Table 1 shows earthquakes with magnitude 7.0 or greater in southwest China.

In southwest China, except for a few earthquakes which occurred in modern times had relatively detailed landslide inventory based on field investigations, such as Luohuo earthquake, Longling earthquake, most of the historical earthquakes were just simply recorded with the place where the big size landslides occurred. Due to this reason, it is difficult to count the landslide number and to calculate the areas affected by landslides. Fortunately, in the 1990s, Chinese Earthquake Administration took charge of collecting and compiling the historical earthquakes catalogue, which was intended to obtain more accurate and reliable information about seismic parameters such as magnitude, epicentre, secondary disasters and so on. As a result of the work, some historical earthquakes could be traced back, then seismic intensity lines can be obtained based on history documents and corresponding field works. Although it is still difficult to draw lines enclosing the landslides based on the historical earthquake catalogue, the seismic intensity line will help. In this paper, the seismic intensity line of VII is used instead to roughly calculate the area affected by landslides. As to the relationship between seismic intensity and landslides distribution, it is said that there are many landslides which occurred in the area with intensity of VI and even lower according to the publications in recent years (Keefer, 2002, 2006; Jibson, 2000; Qi et al., 2010). But in southwest China, studies of documented historical earthquakes and earthquakes which occurred in modern times show that earthquake-induced landslides are prior to occur more likely to within the area with seismic intensity VII or greater (Qiao et al., 1992; Zhou et al; Yang et al., 2002; Wang et al., 2009; Institute of Geography of Sichuan province, 1973, 1974; Earthquake disaster prevention department of State seismological Bureau, 1995, 1999). Qiao's study also showed that some earthquake-triggered landslides were mostly concentrated around the epicentre regions such as the Batang earthquake in 1870, Diexi earthquake in 1933 and so on (Qiao et al., 1992). Certainly, there are some earthquake-triggered landslides in the area with an intensity line of VI, such as Longling earthquake that will be introduced in this paper later, but the number and size of landslides in these events are far smaller. The difference between the characteristics of landslide distribution in the different regions reveals the influence of local geological and topographic conditions on landslide development. Though sometimes it may underestimate the landslide area using the seismic intensity line of VII for calculating the affected area in the study region, considering characteristics of landslide distribution and the limitation of data, it may be an acceptable way to deal with the data. 
Table 1. Earthquakes with magnitude 7.0 or greater in southwest China.

\begin{tabular}{|c|c|c|c|c|c|c|c|c|c|}
\hline \multirow[t]{2}{*}{$\begin{array}{r}\text { Earthquake } \\
\text { No. }\end{array}$} & \multirow[t]{2}{*}{$\begin{array}{l}\text { Date } \\
\text { (yy-mm-dd) }\end{array}$} & \multirow[t]{2}{*}{$\begin{array}{r}\text { Focal } \\
\text { depth }(\mathrm{km})\end{array}$} & \multicolumn{2}{|c|}{ Epicentre } & \multirow[t]{2}{*}{ Magnitude } & \multirow[t]{2}{*}{ Location } & \multirow[t]{2}{*}{$\begin{array}{l}\text { Epicentre seismic } \\
\text { intensity }\end{array}$} & \multirow[t]{2}{*}{$\begin{array}{r}\text { Area affected } \\
\text { landslide }\left(\mathrm{km}^{2}\right)\end{array}$} & \multirow[t]{2}{*}{ Reference* } \\
\hline & & & Latitude & Longitude & & & & & \\
\hline 1 & $814-4-6$ & & 27.9 & 102.2 & 7 & Xichang,Sichuan & IX & & $\mathrm{E}$ \\
\hline 2 & $1216-3-24$ & & 28.4 & 103.8 & 7 & Leibo,Sichuan & IX & & $\mathrm{E}$ \\
\hline 3 & $1500-1-13$ & & 24.9 & 103.1 & 7 & Yiliang,Yunnan & $>=\mathrm{IX}$ & & $\mathrm{E}$ \\
\hline 4 & $1515-6-27$ & & 26.7 & 100.7 & 7.75 & Yongsheng,Yunnan & $\mathrm{X}$ & 20010 & $\mathrm{E}, \mathrm{S}$ \\
\hline 5 & $1536-3-29$ & & 28.1 & 102.2 & 7.5 & Xichang,Sichuan & $\mathrm{X}$ & & E \\
\hline 6 & $1588-8-9$ & & 24 & 102.8 & 7 & Jianshui, Yunnan & $>=\mathrm{IX}$ & 8843 & $\mathrm{E}, \mathrm{S}$ \\
\hline 7 & $1652-7-13$ & & 25.2 & 100.6 & 7 & Midu,Yunnan & IX+ & 4392 & $\mathrm{E}, \mathrm{S}$ \\
\hline 8 & $1713-9-4$ & & 32 & 103.7 & 7 & Maoxian,Sichuan & IX & & E \\
\hline 9 & $1725-8-1$ & & 30 & 101.9 & 7 & Kangding,Sichuan & IX & & $\mathrm{E}$ \\
\hline 10 & $1733-8-2$ & & 26.3 & 103.1 & 7.75 & Dongchuan, Yunnan & $\mathrm{X}$ & 15480 & $\mathrm{E}, \mathrm{S}$ \\
\hline 11 & $1786-6-1$ & & 29.9 & 102 & 7.75 & Kangding,Sichuan & & & E \\
\hline 12 & $1786-6-10$ & & 29.4 & 102.2 & 7 & Luding,Sichuan & & & E \\
\hline 13 & $1789-6-7$ & & 24.2 & 102.9 & 7 & Huaning, Yunnan & IX+ & 8416 & $\mathrm{E}, \mathrm{S}$ \\
\hline 14 & $1799-8-27$ & & 23.8 & 102.4 & 7 & Shiping,Yunnan & IX & 5647 & $\mathrm{E}, \mathrm{S}$ \\
\hline 15 & $1816-12-8$ & & 31.4 & 100.7 & 7.5 & Luhuo, Sichuan & $\mathrm{X}$ & & E \\
\hline 16 & $1833-9-6$ & & 25 & 103 & 8 & Songming,Yunnan & $>=X$ & 27480 & $\mathrm{E}, \mathrm{S}$ \\
\hline 17 & $1850-9-12$ & & 27.7 & 102.4 & 7.5 & Xichang,Sichuan & $\mathrm{X}$ & 11710 & $\mathrm{E}, \mathrm{S}$ \\
\hline 18 & $1870-4-11$ & & 30 & 99.1 & 7.25 & Batang,Sichuan & $\mathrm{X}$ & & $\mathrm{E}$ \\
\hline 19 & $1887-12-16$ & & 23.7 & 102.5 & 7 & Shiping,Yunnan & IX+ & 2946 & $\mathrm{E}, \mathrm{S}$ \\
\hline 20 & $1893-8-29$ & & 30.6 & 101.5 & 7 & Daofu,Sichuan & IX & & $\mathrm{E}$ \\
\hline 21 & $1904-8-30$ & & 31 & 101.1 & 7 & Daofu,Sichuan & IX & & $\mathrm{E}$ \\
\hline 22 & $1913-12-21$ & & 24.15 & 102.45 & 7 & Eshan,Yunnan & IX & 2839 & $\mathrm{E}, \mathrm{S}$ \\
\hline 23 & $1923-3-24$ & & 31.3 & 100.8 & 7.3 & Luhuo,Sichuan & $\mathrm{X}$ & 1868 & $\mathrm{E}, \mathrm{S}$ \\
\hline 24 & $1925-3-16$ & & 25.7 & 100.2 & 7 & Dali,Yunnan & $\mathrm{IX}+$ & 4888 & $\mathrm{E}, \mathrm{S}$ \\
\hline 25 & $1933-8-25$ & & 32 & 103.7 & 7.5 & Maowen,Sichuan & $\mathrm{X}$ & 7161 & $\mathrm{E}, \mathrm{S}$ \\
\hline 26 & $1941-5-16$ & & 23.7 & 99.4 & 7 & Gengma, Yunnan & IX & 2654 & E, $S$ \\
\hline 27 & $1948-5-25$ & & 29.5 & 100.5 & 7.3 & Litang,Sichuan & $\mathrm{X}$ & 6110 & $\mathrm{E}, \mathrm{S}$ \\
\hline 28 & $1955-4-14$ & & 30 & 101.9 & 7.5 & Kangding,Sichuan & $\mathrm{X}$ & 4416 & $\mathrm{E}, \mathrm{S}$ \\
\hline 29 & $1970-1-5$ & 13 & 24 & 102.7 & 7.8 & Tonghai,Yunnan & $\mathrm{X}+$ & 8479 & $\mathrm{E}, \mathrm{ES}$ \\
\hline 30 & $1973-2-6$ & 11 & 31.48 & 100.53 & 7.6 & Luhuo,Sichuan & $\mathrm{X}$ & 409 & E, GS, C \\
\hline 31 & $1974-5-11$ & 14 & 28.2 & 103.9 & 7.1 & Daguan,Yunnan & IX & 610 & E,GS \\
\hline 32 & $1976-5-29$ & 21 & 24.45 & 98.87 & 7.4 & Longling,Yunnan & IX & 3382 & $\mathrm{E}, \mathrm{GS}$ \\
\hline 34 & $1976-8-16$ & 15 & 32.61 & 104.13 & 7.2 & Songpan,Sichuan & IX & 1991 & $\mathrm{E}, \mathrm{ES}$ \\
\hline 36 & $1988-11-6$ & 16 & 23.37 & 99.5 & 7.2 & Gengma, Yunan & $\mathrm{X}$ & 5966 & $\mathrm{E}, \mathrm{ES}$ \\
\hline 37 & $1996-2-3$ & 10 & 27.083 & 100.267 & 7 & Lijiang,Yunnan & IX & 8433 & $\mathrm{E}, \mathrm{EY}$ \\
\hline 38 & $2008-5-12$ & 14 & 31 & 103.4 & 8 & Wenchuan,Sichuan & XI & 21000 & $\mathrm{~N}$ \\
\hline
\end{tabular}

* E: Earthquake disaster prevention department of China Earthquake Administration (1995, 1999); ES: Earthquake Administration of Sichuan Province; C: Chengdu earthquake investigation team of State seismological Bureau; EY: Earthquake Administration of Yunnan Province; GS: Institute of Geography of Sichuan province; S: Southwest China Intensity Zoning team, State Seismological Bureau; N: National Wenchuan Earthquake experts committee.

\subsection{Earthquake-induced landslides}

As mentioned before, southwest China is located in the southeastern margin of the Tibetan Plateau. During the tectonic evolution, this region experienced tectonic movements many times and today it is still one of the highest seismicity regions in China. In addition to the steep topography, earthquake-induced landslide is a kind of common hazard phenomena in this region.

In this paper, 3 earthquakes (Luhuo earthquake in 1973, Zhaotong earthquake in 1974, and Longling earthquake in 1976) will be introduced. These earthquakes occurred in modern time and landslides triggered during the events were recorded comparatively in detail through post-seismic field investigations.
In China, Chinese Seismic Intensity is used widely in the earthquake-triggered landslides research. Table 2 shows the relationship of Chinese Seismic Intensity value and peak ground acceleration.

\subsubsection{Luhuo earthquake in 1973}

Luhuo earthquake occurred in Luhuo county, Sichuan province, on 6 February 1973. The macro-epicentre was located at $31.48^{\circ} \mathrm{N}-100.53^{\circ} \mathrm{E}$. Mainshock magnitude is 7.6 with focal depth $11 \mathrm{~km}$. Epicentre seismic intensity is up to X (Fig. 4). 


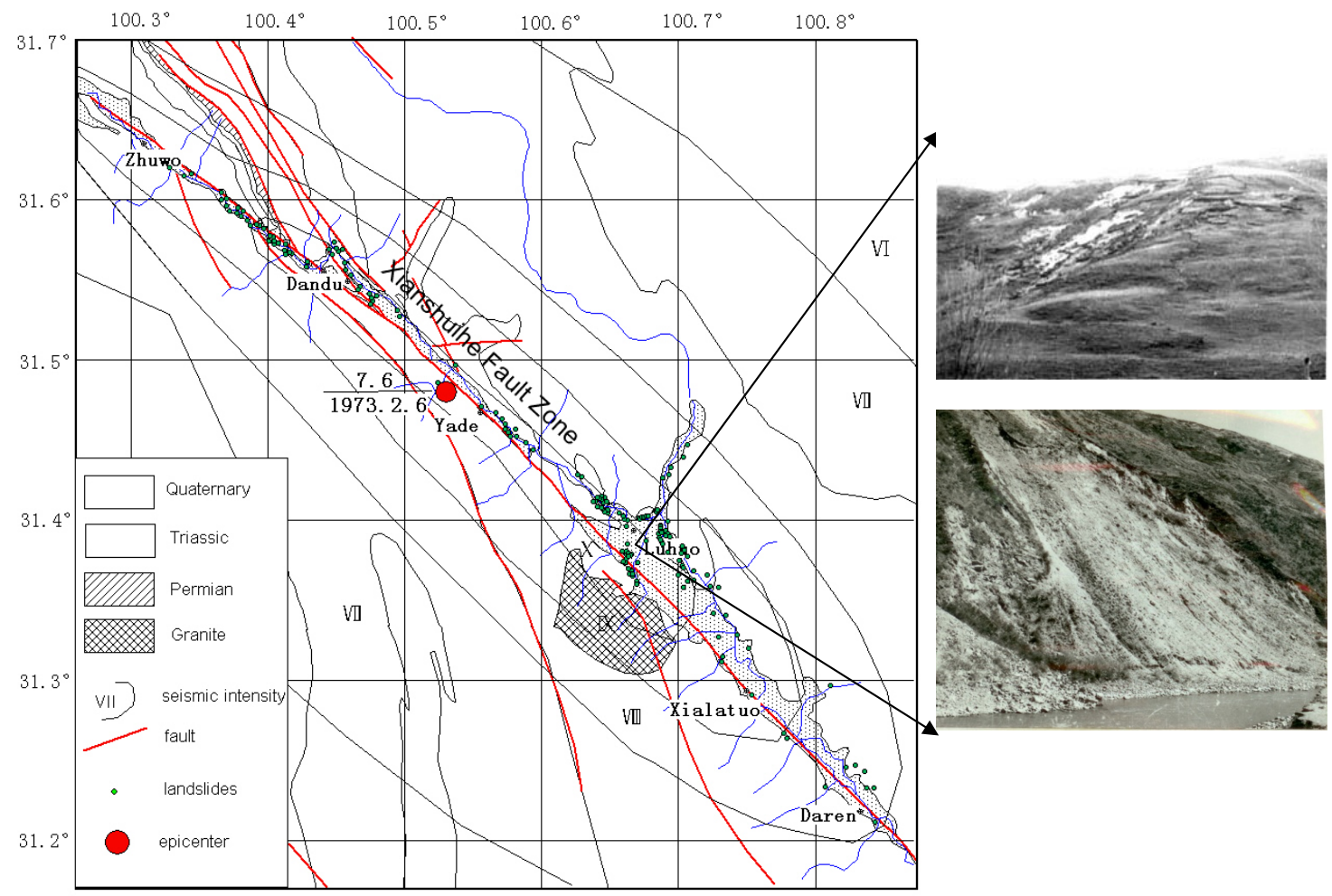

Fig. 4. Geological map of Luhuo earthquake area and locations of earthquake-triggered landslides (revised from the Institute of Geography of Sichuan province. Photos are from the Institute of Geology, State Seismology Bureau).

Table 2. Distribution of Peak Ground Acceleration Corresponding to Each of the Chinese Seismic Intensity values (Li et al., 2008).

\begin{tabular}{lcccccc}
\hline Chinese seismic Intensity & $<$ VI & VI & VII & VIII & IX & $\geq X$ \\
\hline Peak Ground Acceleration (gal) & $10.0-44.9$ & $45.0-89.9$ & $90.0-177.9$ & $178.0-353.9$ & $354.0-707.9$ & $\geq 708.0$ \\
\hline
\end{tabular}

\section{Geology and geomorphology}

The main affected area of Luhuo earthquake present at Daxueshan Mountain range, with an average elevation of $3800 \mathrm{~m}$. Terrain in this region changes sharply. The Xianshuihe river runs from northwest to southeast along the Xianshuihe fault zone, companied by narrow valleys alternating with wide valleys. At narrow valley, the bank is steep and the river bed gradient is big, while at wide valley, the bank is moderate and river bed gradient is small.

In this area, the outcropped strata are simple, which only include Permian, Triassic and Quaternary System. The lower Permian stratum is mainly composed of limestone, while the upper Permian stratum is composed of basalt and shale. The Triassic stratum is some kind of metamorphic flysch formation. The component of Quaternary strata is river-terrace gravel layer, which mostly distribute along the Xianshuihe valley.
Field investigation found Xianshuihe fault was the seismic fault responsible for Luhuo earthquake. Taking account of fault activity, Xianshuihe fault can be divided into two parts bounded at Moxi: the northwest part of Xianshuihe fault has the character of left-lateral strikeslip fault, while southeast part has the reverse component (Xu, et al., 2005).

2. Landslides caused in the earthquake

The epicentre region has a profile of $41 \mathrm{~km}$ in length, and $4.5 \mathrm{~km}$ in width. Within this region, all of the Tibet style buildings were collapsed, and the ground crack distributed in groups or belts. Landslides and collapses can be seen everywhere (Fig. 3).

Post-earthquake investigation found that the landslides spatial distribution was controlled by the Xianshuihe fault zone, almost all of the landslides and collapses occurred in the Xianshuihe Valley along the faults. The landslide affected area is around $70 \mathrm{~km}$ in length along 
Table 3. Number of earthquake-induced landslide in different seismic intensity area.

\begin{tabular}{lrr}
\hline $\begin{array}{l}\text { Seismic } \\
\text { intensity }\end{array}$ & $\begin{array}{r}\text { Number of } \\
\text { landslide }\end{array}$ & $\begin{array}{r}\text { Percent } \\
\%\end{array}$ \\
\hline X & 96 & 70.1 \\
IX & 37 & 27.0 \\
VIII & 4 & 2.9 \\
\hline Total & 137 & 100 \\
\hline
\end{tabular}

the valley, and the widest part is less than $2 \mathrm{~km}$. In total, there are 137 landslides recorded by the field investigation group. With the increasing of seismic intensity, the number of landslides is increasing. The landslides distribution in different seismic intensity area is shown in Table 3. Among these 137 landslides, only one landslide occurred in Permian limestone, whereas all of others were found in Quaternary accumulation layer. Statistical studies also show that the favourite range of slope angles for landslides is between $30^{\circ}$ and $50^{\circ}$ degree. All the landslides occurred in the area with seismic intensity above VIII (Institute of Geography of Sichuan province, 1973).

\subsubsection{Zhaotong earthquake in 1974}

Zhaotong earthquake occurred at the boundary region of Yongshan County and Daguan County of Yunnan province, on 11 May 1974. The macro-epicentre is at the $103.9^{\circ} \mathrm{E}$, $28.2^{\circ} \mathrm{N}$. Mainshock magnitude is $M_{\mathrm{s}}=7.1$ with focal depth $8 \mathrm{~km}$. Epicentre seismic intensity is up to IX (Fig. 5).

\section{Geology and geomorphology}

The affected area of Zhaotong earthquake is located in the northern part of eastern Yunnan plateau. This region is kind of undulating hills with elevation around $1300 \sim 1800 \mathrm{~m}$. In the study region, almost all of the strata from the Sinian Period to Quaternary period are outcropped. The tectonics in Quaternary system distribute along the rivers, form the river terrace and the river beds.

2. Landslides triggered in this earthquake

Zhaotong earthquake triggered lots of landslides. Most of the landslides occurred in the epicentre region of seismic intensity IX, some distributed in the area with seismic intensity XIII or XII (Fig. 5). Landslides were seldom found beyond these areas. The places where landslides developed usually have steep slope angle $26 \sim 45^{\circ}$, while rock avalanche can be found at the steeper places and fault fractural zone. Only one landslide slid along the bedding layer in the Permian limestone, whereas all others occurred in the Quaternary
Table 4. Distribution of landslides by slope angle (from Institute of Geography of Sichuan province).

\begin{tabular}{lccccc}
\hline Slope angle & $16^{\circ}-25^{\circ}$ & $26^{\circ}-35^{\circ}$ & $36^{\circ}-45^{\circ}$ & $46^{\circ}-55^{\circ}$ & total \\
\hline Number of landslides & 5 & 4 & 13 & 6 & 28 \\
Percent (\%) & 17.8 & 14.3 & 46.4 & 21.5 & 100 \\
\hline
\end{tabular}

Table 5. Distribution of rock avalanches by slope angle(from Institute of Geography of Sichuan province).

\begin{tabular}{lccccc}
\hline Slope angle & $<50^{\circ}$ & $51^{\circ}-60^{\circ}$ & $61^{\circ}-70^{\circ}$ & $77^{\circ}$ & total \\
\hline Number of rock avalanches & 3 & 8 & 19 & 9 & 39 \\
Percent $(\%)$ & 7.4 & 20.5 & 48.7 & 23.1 & 100 \\
\hline
\end{tabular}

residual deposits and deep weathered layer. For rock avalanches, they concentrated in the Permian limestone and Triassic sandshale which are deeply weathered and have developed joints.

Tables 4 and 5 show the relationship between landslides and slope angle, rock avalanches and slope angle, respectively; Table 6 shows relationship between landslides, rock avalanches and seismic intensity (Institute of Geography of Sichuan province, 1974).

\subsubsection{Longling earthquake in 1976}

Longling earthquake occurred at Longling County, Yunan province on 29 May 1976. Actually, Longling earthquake contains two mainshocks with magnitude of 7.3 and 7.4. Epicentre of the magnitude 7.3 mainshock is at $98.83^{\circ} \mathrm{E}$, $24.62^{\circ} \mathrm{N}$, and epicentre of the magnitude 7.4 mainshock is at $98.87^{\circ} \mathrm{E}, 24.45^{\circ} \mathrm{N}$. As a result, there are 2 epicentre seismic zones formed with seismic intensity IX.

\section{Geology and geomorphology}

The study area is located in the western part of Yunnan province, on the west side of Lancangjiang deep fault zone. It is composed of a series of anticlines, synclines and faults. This region has experienced intense tectonic movement, and subjected to frequent severe earthquakes. Frequent and sustainable magmatic actions resulted in magnetite, which formed in different periods from Caledonian and Hercynian to Quaternary. Geomorphologically, the study region takes on an aspect of structural basins alternating with hills. It has 6 distinct levels of planation surface bounded by faults. Their elevations from top to bottom are: higher than $2400 \mathrm{~m}$, $2200 \mathrm{~m}, 2000 \mathrm{~m}, 1800 \mathrm{~m}, 1530 \sim 1600 \mathrm{~m}$, and $1000 \mathrm{~m}$, respectively. Structural basins usually are $100 \mathrm{~m}$ lower than planation surfaces around them.

Lithology in this region can be classified as 4 types: granite, sedimentary rocks, metamorphic rock and Quaternary basalt. The surface part of Granite has been 


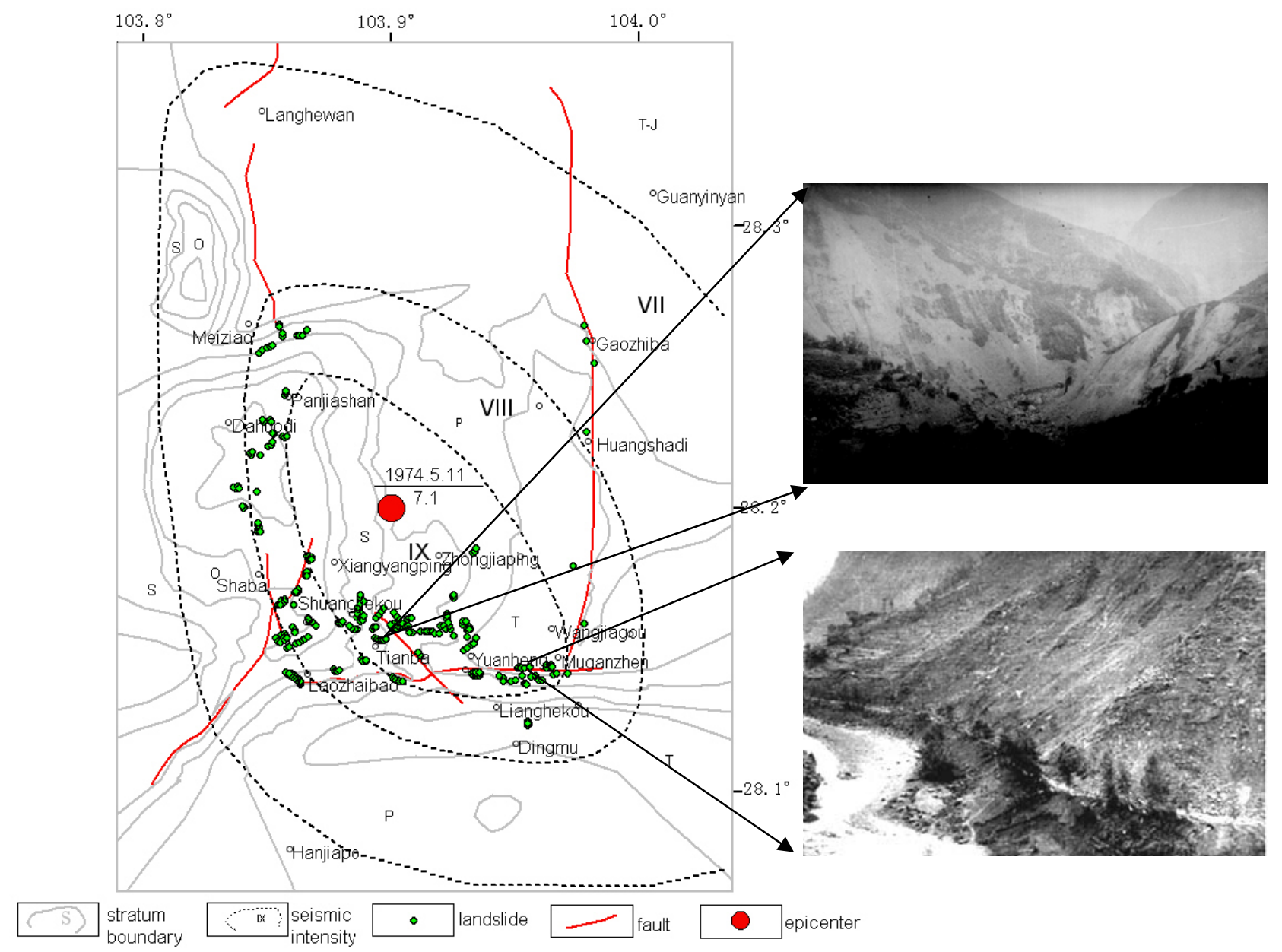

Fig. 5. Geological map of Zhaotong earthquake area and locations of earthquake-triggered landslides (revised from Institute of Geography of Sichuan province. Photos are from Institute of Geology, State Seismology Bureau).

Table 6. Distribution of landslides by seismic intensity (from Institute of Geography of Sichuan province).

\begin{tabular}{llccccr}
\hline \multicolumn{2}{c}{ Seismic intensity } & IX & VIII & VII & VI & total \\
\hline \multirow{2}{*}{ Rock avalanches } & Number & 10 & 23 & 6 & 0 & 39 \\
& Percent (\%) & 25.6 & 59.0 & 15.4 & 0 & 100.0 \\
Landslides & Number & 17 & 4 & 7 & 0 & 28 \\
& Percent (\%) & 60.7 & 14.3 & 25.0 & 0 & 100.0 \\
\hline
\end{tabular}

deeply weathered and becomes a loose soil layer. A lot of shallow landslides occurred in this weathered residue during the Longling earthquake. The combination of lithological condition and topographic condition is prone to induce shallow landslides.

2. Landslides generated by the earthquake

Longling earthquake triggered lots of landslides, which spread through a wide area in groups (Fig. 6). For a sin- gle landslide, it usually has a dimension of $20-100 \mathrm{~m}$ in length, $10-60 \mathrm{~m}$ in width. Most of the landslides occurred in the residual deposits of soil, with a thickness ranging from 1 to $2 \mathrm{~m}$ and the maximum thickness 4 $5 \mathrm{~m}$. The places where landslides developed are usually at the river valleys with steep slope angle $35-40^{\circ}$ and height deviation greater than $200 \mathrm{~m}$. Lots of the landslides occurred in the region of seismic intensity greater than VII, some scattered in the area with seismic intensity VI (Institute of Geography of Sichuan province, 1976).

Of these 3 earthquake examples, which occurred in different parts of the study region and had the similar features in landslides distribution with steep topographic features and seismic intensity, Luhuo earthquake, which occurred at the north part of the study region, triggered landslides that are narrowly limited to Xianshuihe valley within the seismic intensity line of VIII, and showing a more close relationship with the seismic faults than the other 2 earthquakes. In 


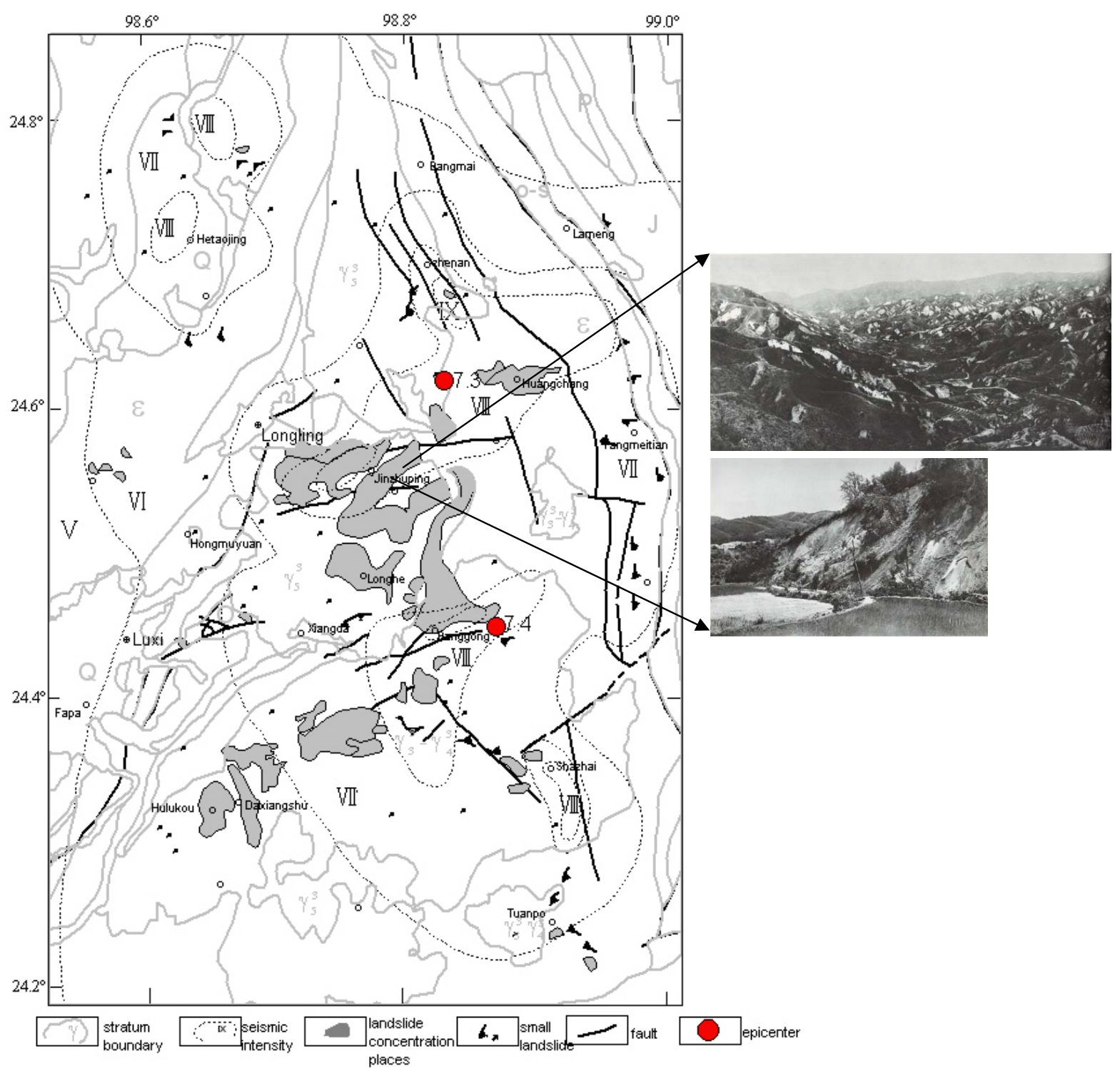

Fig. 6. Geological map of Longling earthquake area and locations of earthquake-triggered landslides (revised from Institute of Geography of Sichuan province. Photos are from Institute of Geology, State Seismology Bureau).

addition, there are some differences existing in the landslide types and landslide materials. More detailed information is needed to explore the reasons that caused dissimilarity of landslides in earthquakes in southwest China.

\subsection{Areas affected by the earthquake-triggered landslides}

Keefer (1984) defined the area affected by the earthquake by: drawing a boundary around all the reported landslide localities and calculating the size of the region enclosed (Keefer, 1984). Bommer et al., used the same technique to calculate the landslide-affected area in his study of earthquake-induced landslides in Central America (Bommer et al., 2002). In this study, due to incomplete information of the earthquakes, two measurements are taken to calculate the area affected by the landslides: (1) for the landslides which have detailed information of characteristics like location, scale, number and so on, the area affected by landslides is defined as a region enclosing all the recorded landslides. This is the same as Keefer's definition (1984); (2) for the landslides which are lacking the necessary information, the area of associated landslides is defined as a region enclosed by the isoseismal line of seismic intensity VII. Regarding the available data, most of the landslides or rockfalls could be found within seismic intensity VII. The previous examples also show that landslides mainly distribute in the places bounded by seismic intensity VII. 


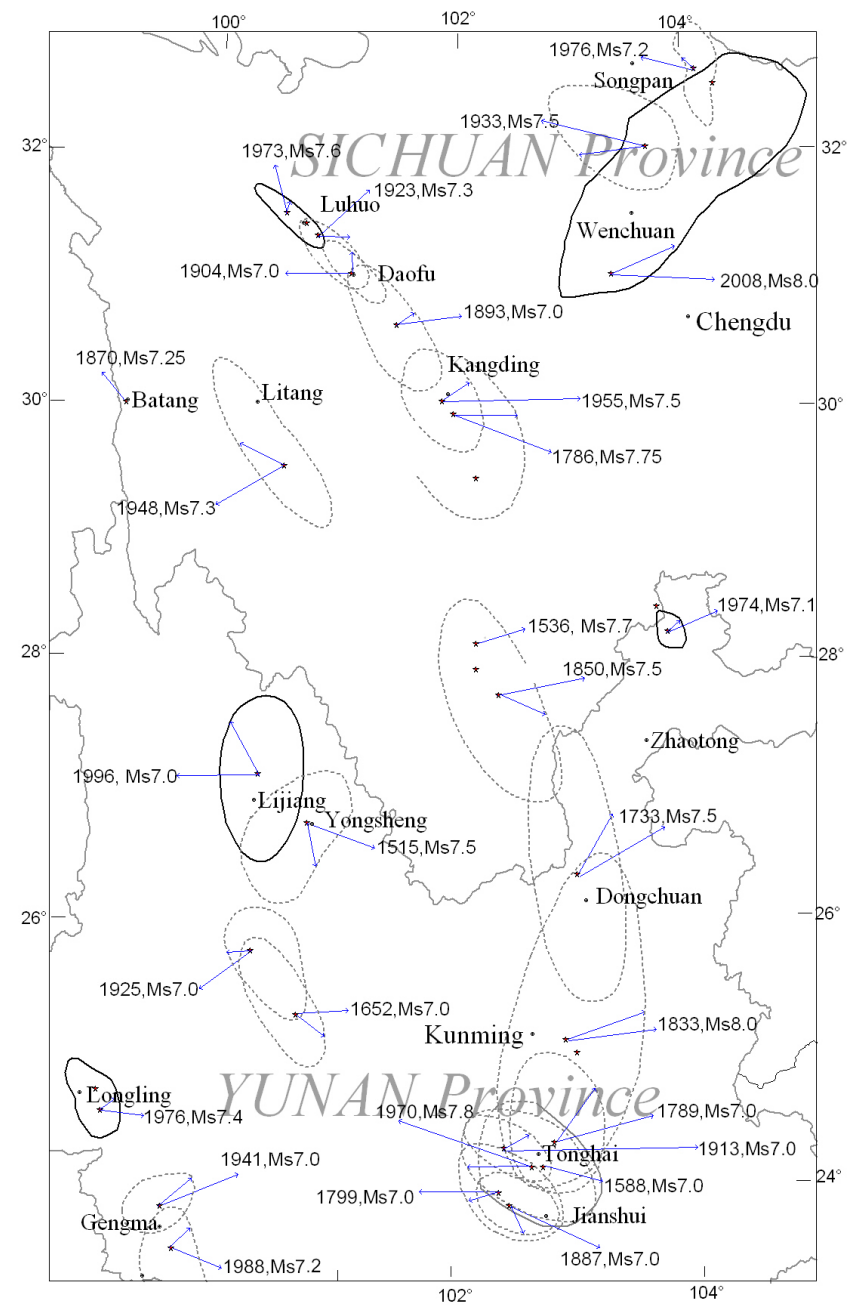

Fig. 7. Earthquake epicentres and area of associated landslides in southwest China (solid lines are the earthquakes having detailed landslides records, dash lines are inferred from the history documents, which using seismic intensity line of VII for instead).

Since the smallest earthquake could cause landslides bigger than 4.0 (Keefer, 1984), 835 historical earthquakes of $M \geq 4.7$ occurred in the study region are supposed to trigger landslides. Actually, only a part of the historical earthquakes are documented with landslide reports due to sparsely inhabited and an uncultured situation in the past time. Generally, the area affected by earthquake shows strong correlation with earthquake magnitude, and earthquakes with a bigger magnitude can cause a wider influencing area (Keefer, 1984; Bommer et al., 2002; Rodríguez et al., 1999). In the study region, there are, in total, 37 historical earthquakes with magnitude 7.0 or greater recorded (Table 1). But only a few of these historical earthquakes that occurred in the modern time had detailed field investigation (Earthquake-resistant and damage prevention department of State Seismic Bureau, 1995; Earthquake-resistant and damage prevention department of

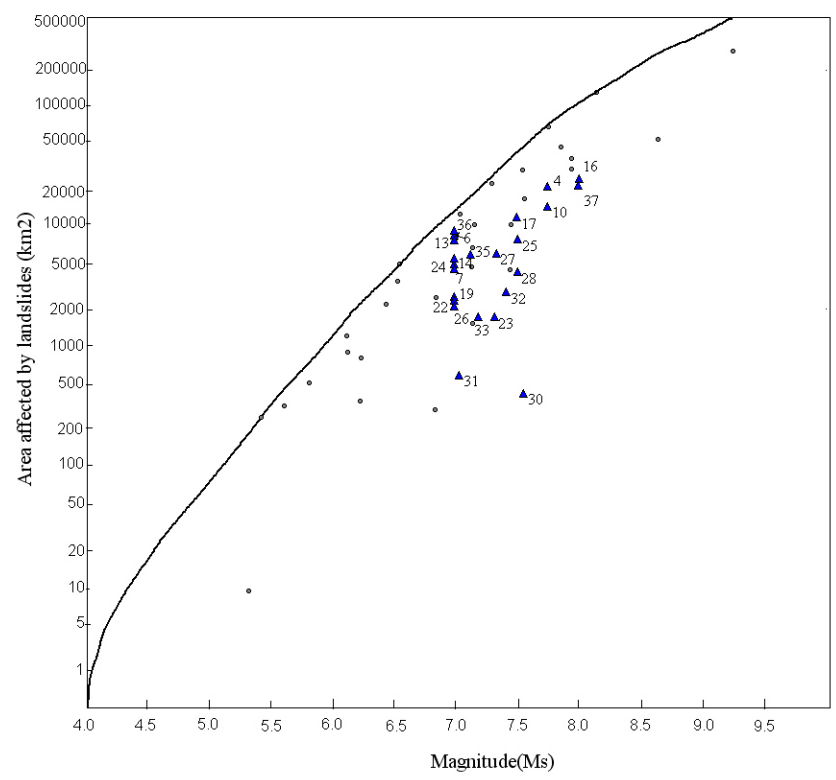

Fig. 8. Areas affected by landslides triggered by earthquakes with magnitude $\geq 7.0$ in southwest China as a function of magnitude. Upper bound line and dots are from Keefer (1984). The triangles and numbers refer to the identification of individual events in Table 1.

China Earthquake Administration Bureau, 1999; Institute of Geography of Sichuan province, 1973, 1974, 1976). Finally, only 24 earthquakes with magnitude 7.0 or greater are used to calculate the landslide affected areas in this study.

Figure 7 shows the earthquake epicentres and areas of associated landslides in southwest China. Figure 8 shows the correlations between the earthquake magnitude and the areas affected by the landslides, and the upper bound used here is identified by Keefer (1984).

From these 2 figures, the first observation that can be made is that all of the data dots representing landslides fall under the upper-bound line identified by Keefer. This means that the relationship between seismic magnitude and landslides affected area in southwest China is consistent with the knowledge obtained by Keefer in 1984. In this study, though there are 2 approaches used to calculate the size of affected area, and different measurements would result in a different estimated size of landslides area, the affected areas can be compared when the same measurement is used.

From Figs. 7 and 8, it can be seen that with the same earthquake magnitude, the areas affected by the landslides vary enormously. For example, earthquakes of No. 6, 13, 14, 24, $7,19,22$ and 26 are all with magnitude 7.0, however the areas affected by landslides change greatly from 2600 to $8843 \mathrm{~km}^{2}$ when the same measurement is used.

However, the size and shape of the landslide-affected area are very similar in some areas where there are frequent occurrences of strong earthquakes, such as in Xianshuihe fault zone and Shiping-Jianshui fault zone (Figs. 6 and 7). 


\section{Conclusions}

Although there are hundreds of earthquakes generated with supposed generated landslides in southwest China in history, the data which can be used for deep analysis is extraordinarily limited. This paper provides several earthquake examples which have comparatively detailed records of landslide distribution, and also presents a set of data regarding earthquakes with magnitudes 7.0 or greater in this region. Despite the fact that the dataset is not comprehensive, the work in this paper still allows some useful preliminary research that may be helpful in further work.

Primary analysis shows that steep slope degree and high seismic intensity are the common characteristic of the landslides triggered by strong earthquakes in southwest China. Generally, the spacial distribution of landslides triggered by earthquake is controlled by the tectonics, such as Wenchuan earthquake and Luhuo earthquake, which occurred at Longmenshan fault zone and Xianshuihe fault zone, respectively. Landslides spread along the seismic faults and decreased quickly in the direction perpendicular to seismic faults (Huang and Li, 2008; Wang et al., 2008). A comparison of the data with previous observations made during the 1973 Luhuo, 1974 Zhaotong and 1976 Longling earthquakes show significant similarities in the distributions of the landslides with earthquake intensity and steep slope. It can be concluded that strong earthquakes, steep topography and fragile geological environment are main reasons responsible for serious landslides in southwest china.

The most important conclusion drawn from the data and the correlations explored within this study is that there are significant differences in the nature of earthquake-triggered landslides in this region. In the whole study region, even though some earthquakes had the same seismic magnitudes, there is a great difference between the areas affected by landslides. While at the same tectonic place or fault belt, area affected by landslides presented similar outline and size. The difference of the characteristics of landslide distribution reveals the influence of local geological and topographic conditions on landslides occurrence.

In spite of the strong correlation between earthquake magnitude and the area affected by landslides, the apparent conclusion that earthquake magnitude is good criteria for predicting seismically induced landslides is not very satisfactory even with the simplest method for predict earthquaketriggered landslides. When applying earthquake magnitude for assessing earthquake-triggered landslides hazard at 1 grade (ISSMGE, 1999), it is important to consider the local geological condition and history earthquake background, rather than to simply rely on the basis of geographical regions. The knowledge drawn from this study at the same tectonic place or fault belt - the area affected by landslides presenting similar outline and size - would be useful to assess earthquake-triggered landslides hazard at a regional scale.
Also, though the magnitude is important for earthquaketriggered landslides prediction in the long term, more and more researches show that the ground shaking intensity influences the occurrence of landslides to a deeper degree. Geological setting in a wider region will need more attention. For example, in northwest China, where the Loess Plateau is the most widely distributed region of loess on earth, earthquaketriggered landslides in northwest China show different distribution characteristics compared to earthquake-triggered landslides in southwest China. Earthquake with magnitude 5.0 or greater will cause serious geotechnical disasters in the loess sites (Wang, 2003). Deep research about earthquaketriggered landslides in Loess Plateau in China will be conducted in the near future.

Acknowledgements. This research was supported by Ministry of Industry and Information Technology of People's Republic of China (Grant No. 2010ZX03006-007) and the Institute of Geology, China Earthquake Administration (Grant No. IGCEA1006). The authors would like to express deep thanks to the faculty, staff and drivers for their support in the work. Lots of thanks to the anonymous reviewers for their insightful reviews that greatly improved the manuscript.

Edited by: M. E. Contadakis

Reviewed by: two anonymous referees

\section{References}

Australian geomechanics society landslide zoning working group: Guideline for landslide susceptibility, hazard and risk zoning for land use planning, Australian Geomechanics, 42, March, 2007.

Bommer, J. J., Carlos, E., and Rodríguez, C. R.: Earthquakeinduced landslides in Central America, Eng. Geol., 63, 189-220, 2002.

Cornell, C. A.: Engineering Seismic Risk Analysis, Bull. Seism. Soc. Am., 58, 1583-1606, 1968.

Chen, X. L., Nobuaki, K., Ryosuke, T., and Kato, N.: Prediction of slope failure due to earthquake, Chinese Science Bulletin, 54, 2888-2894, 2009.

Chen, X. L., Zhou, B. G., Ran, H. L., Yamamoto, Y., and Hyodo, M.: Geohazards induced by the Wenchuan Earthquake, Geologically Active, Taylor \& Francis Group, London, ISBN 978-0-41560034-7, 2010.

Chengdu earthquake investigation team of State seismological Bureau: Reports on investigation of Luhuo earthquake occurred on Feb. 6, 1973 (in Chinese).

Chinese seismic ground motion zoning working group: Seismic zonig map in China, Beijing, Standards Press of China, 2001 (in Chinese).

Earthquake Administration of Sichuan Province: 1976 Songpan earthquake (in Chinese), Beijing, Seismological Press, 1979 (in Chinese).

Earthquake Administration of Sichuan Province: 1981 Daofu earthquake (in Chinese), Beijing, Seismological Press, 1986 (in Chinese).

Earthquake disaster prevention department of State seismological Bureau: Catalogue of historical strong earthquakes in China 
(23rd century B. C. to 1911), Beijing, Seismological Press, 1995 (in Chinese).

Earthquake disaster prevention department of China Earthquake Administration: Catalogue of modern earthquakes in China, Beijing, China Science and Technology Press, 1999 (in Chinese).

Earthquake Administration of Yunnan Province: 1996 Lijiang earthquake (in Chinese), Beijing, Seismological Press, 1998 (in Chinese).

Guzzetti, F., Carrara, A., Cardinali, M., and Reichenbach, P.: Landslide hazard evaluation: a review of current techniques and their application in a multi-scale study, Central Italy, Geomorphology, 31, 181-216, 1999.

Heckerman, D.: Probabilistic interpretation of MYCIN's certainty factors, Uncertainty in Artificial Intelligence, edited by: Kanal, L. N. and Lemmer, J. F., Elsevier, New York, 298-311, 1986.

Huang, R. Q. and Li, W. L.: A study on the development and distribution rules of geohazards triggered by " 5.12 " Wenchuan Earthquake, Chinese J. Rock Mech. Eng., 27, 2585-2592, 2008 (in Chinese).

Institute of Geography of Sichuan province: Report of investigation on Luhuo earthquake triggered landslides on Feb. 6, 1973 (in Chinese).

Institute of Geography of Sichuan province: Report of investigation on Daguan-Yongshan earthquake triggered rock fall, landslides, debris flow on Feb. 6, 8, 1974 (in Chinese).

Institute of Geography of Sichuan province: Report of investigation on Longling earthquake triggered landslides on May 29, 1976 (in Chinese).

Institute of Geology, State Seismological Bureau: The photo album of eight strong earthquake disasters in China, Beijing, Seismological Press, 1983.

ISSMGE: Manual for Zonation on Seismic Geotechnical Hazards (revised version), Technical Committee for Earthquake Geotechnical Engineering, TC4, International Society for Soil Mechanics and Geotechnical Engineering, The Japanese Geotechnical Society, Tokyo, 1999.

Jibson, R. W., Harp, E. L., and Michael, J. A.: A method for producing digital probabilistic seismic landslide, Eng. Geol., 58, 271289, 2000.

Keefer, D. K.: Landslides caused by earthquakes, Geol. Soc. Am. Bull., 95, 406-421, 1984.

Li, P. (Ed.): Southwest China Intensity Zoning team, State Seismological Bureau, Seismic intensity zonation for the marginal region of the Qinghai-Tibet plateau: a case study of the Xichang prefecture, Beijing, China Academic Publishers, 1985.

Li, X. J., Zhou, Z. H., Huang, M., Wen, R. Z., Yu, H. Y., Lu, D. W., Zhou, Y. N., and Cui, J. W.: Preliminary Analysis of StrongMotion Recordings from the Magnitude 8.0 Wenchuan, China, Earthquake of 12 May 2008[J], Seismol. Res. Lett., 79, 844-854, 2008.

Ma, X. Y. (Ed.): Lithospheric dynamics atlas of China, Beijing, China Cartographic Publishing House, 1989.

National Institute for Land and Infrastructure Management: Ministry of Land, Infrastructure, Transport and Tourism. A study on methodology for assessing the potential of slope failures during earthquakes, Japan, 2004 (in Japanese).

National Wenchuan Earthquake experts committee: Atlas of seismic hazard during Wenchuan Earthquake, Beijing, SinoMaps Press, 2008 (in Chinese).
Qi, S. W., Xu, Q., Lan, H. X., Zhang, B., and Liu, J. Y: Spatial distribution analysis of landslides triggered by 2008.5.12, Wenchuan Earthquake, China, Eng. Geol., 116, 95-108, 2010.

Qiao, J. P. and Pu, X. H.: A preliminary study on the distributive regulation of seismic landslide in Sichuan and Yunnan, J. Seismol. Res., 15, 411-417, 1992 (in Chinese).

Rodríguez, C. E., Bommerb, J. J., and Chandlerb, R. J.: Earthquakeinduced landslides: 1980-1997, Soil Dynam. Earthq. Eng., 18, 325-346, 1999.

Saaty, L. and Wong, M. M.: Projective average family size in rural India by the analytic hierarchy process, J. Math. Soc., 9, 181-209, 1983.

Sassa, K., Fukuoka, H., and Wang, F. W.: Dynamic properties of earthquake-induced large-scale rapid landslides within past landslide masses, Landslides, 2, 125-134, 2005.

Scott, S. B. and Keefer, D. K.: Seismic landslide hazard for the city of Berkeley, California, USGS, Open file, 2001.

Shan, X. J.: Integration and application of remote sensing and geographical information system technology for the evaluation of geological environment, Beijng, Institute of Geology, CEA, 1999 (in Chinese).

Southwest China Intensity Zoning Team: State Seismological Bureau, Investigation of seismology and geology of strong earthquake zone in Sichuan-Yunnan region, Beijing, Seismological Press, 1979 (in Chinese).

Wang, H. B., Sassa, K., and Xu, W. Y.: Analysis of a spatial distribution of landslides triggered by the 2004 Chuetsu earthquakes of Niigata Prefecture, Japan, Nat. Hazards., 41, 43-60, 2007.

Wang, L. M. (Ed.): Loess dynamics, Beijing, Seismological Press, 2003 (in Chinese).

Wang, Y. Q., Xin, H. B., Gao, Y. P., and Zhou, G. S.: Study on comprehensive index method for predicating earthquake-induced landslides, Chinese J. Geotech. Eng., 23, 311-314, 2001 (in Chinese).

Wang, Y. S., Luo, Y. H., Ji, F., Huo, J. J.,Wu, J. F., and Xu, H. B.: Analysis of the controlling factors on geo-hazards in mountainous epicentre zones of the Wenchuan Earthquake. J. Eng. Geol., 16, 759-763, 2008 (in Chinese).

Wen, B. P., Wang, S. J., Wang, E. Z., and Zhang, J. M.: Characteristics of rapid giant landslides in China, Landslides, 4, 247-261, 2004.

Wilson, R. C. and Keefer, D. K.: Predicting areal limits of earthquake-induced landsliding. In evaluating earthquake hazards in Los Angeles region, US Geological Survey, Professional Paper 1360, 317-345, 1985.

Xu, X. W., Zhang, P. Z., and Wen X. Z.: Features of active tectonics and recurrence behaviors of strong eaathquakes in the western Sichuan province and its adjacent regions, Seismol. Geol., 27, 446-461, 2005 (in Chinese).

Yang, T., Deng, R. G., and Liu, X. L.: The distributing and subarea character of the seismic landslides in Sichuan, J. Mountain Sci., 20, 456-460, 2002 (in Chinese).

Yi, G. X., Wen, X. Z., and Xu, X. W.: Study on recurrence behaviors of strong earthquakes for several entireties of active fault zones in Sichuan-Yunnan region, Earthquake research in China, 18, 267276, 2002 (in Chinese).

Yin, Y. P., Wang, F. W., and Sun, P.: Landslide hazards triggered by the 2008 Wenchuan earthquake, Sichuan, China, Landslides, 6, 139-152, 2009. 
Zhang, L. M.: Challenges in multi-hazard risk assessment and management, Geohazard chain in Beichuan Town caused by Great Wenchuan Earthquake, in: Geotechnical Risk and Safety, Taylor and Francis Group, London, 237-244, 2009.

Zhang, P. Z., Deng, Q. D., Zhang, G. M., Ma, J., Gan, W. J., Min, W., Mao, F. Y., and Wang, Q.: Active tectonic blocks and strong earthquakes in the continental of China, Science in China (Ser D), 46 (Suppl), 13-24, 2003.
Zhou, B. G. and Zhang, Y. M.: Some characteristics of earthquakeinduced landslide in southwestern China, Northwestern Seismological Journal, 16, 95-103, 1994. 